\title{
Histological and Histochemical Studies on the Role of Caffeine on Radiation damage of the Liver
}

\author{
* Omaima , S. Essa ; ** Abdel Mawgood A.Isamil and ** Ashraf, M. Moustafe \\ * National Center for Radiation and Technology. \\ **Histology Dept. Faculty of Medicine, AL-Azhar University Cairo, Egypt.
}

\begin{abstract}
:
The present study was designed to evaluate effect of caffeine to gamma irradiated rats.

Forty eight female albino rats (120-150 gm) were divided into four groups (each of them 12 rats). The first group was considered as control. The animals in the second group were injected I.P. with caffeine $(80 \mathrm{mg} / \mathrm{Kg}$ b.w.), the third group exposed to (7Gy) $\gamma$-radiation while the animals in the fourth group injected I.P with caffeine $(80 \mathrm{mg} / \mathrm{Kg}$. b. w.) $1 \mathrm{~h}$ prior to wholebody dose of $\gamma$-rays (7 Gy).

Fresh liver specimens were obtained after 1 and 3 days of treatment. Paraffin sections were prepared for histological study ( $\mathrm{Hx} \&$ E.) and frozen sections were prepared for histochemical study for localization of both acid, alkaline phosphatases and succinic dehgdrogenase enzymes.

The enzymatic activity was quantitatively evaluated and statistically analyzed. The obtained results showed that whole body $\gamma$-irradiation of rats induced definite microscopic changes in the liver represented by periportal fibrosis with some necrotic hepatic tissue. Meanwhile caffeine alone showed histological pattern more or less near to normal. On the other hand $\gamma$-rays combined with I.P. injection of caffeine revealed vaculated hepatocytes with dilated blood sinusoids. Histochemical changes were also observed showing significant increase in both acid phosphatase and succinic dehydrogenase enzymes activity after one and three days post exposure while the alkaline phosphatase enzyme activity showed significant decrease after one day and increase after three days of exposure.

Administration of caffeine (1, 3, 7-trimethylzanthine), a major component of coffee (80 $\mathrm{mg} / \mathrm{Kg}$ body weight), $60 \mathrm{~min}$ prior to whole body lethal dose of gamma-irradiation (7 Gy) resulted in improvement of the radiation induced changes in the activity of measured enzymes.
\end{abstract}

\section{Introduction:}

Exposure to high doses of ionizing radiation is associated with utilization of oxygen by cells resulting in production of highly reactive free radicals implicating tissue damage (Packer 1991) and appears in several forms of cellular injury (Boner et al., 1988).

Caffeine, a major component of coffee is an antioxidant radioprotector against the oxic pathway of radiation damage in a wide range of cells and organisms (George et al., 1999). Moreover, radioprotection could also be possibly due to a mutually inhibitory reaction of caffeine molecules with the $\gamma$-radiation induced oxygen reactive sites (Kesaven et al., 1978).

Protection from $\gamma$-rays, still nterest of many radiobiologists, trying to achieve less toxic substance with maximum protecting action against radiation effects.

\section{Material and Methods:}

Forty eight female albino rats weighing from 120-150 gm were used. Animals were housed in cages under good ventilation condition and adequate stable standard diet.

Irradiation was performed by gamma cell 40 (cesium-137) source belonging to 
the National Center for Radiation Research and Technology (NCRRT). This cesium source offers a dose rate of $1.367 \mathrm{rad} / \mathrm{sec}$. Caffeine was purchased from ElGamhoriya company, dissolved in saline and I. P. injected $(80 \mathrm{mg} / \mathrm{Kg}$ b.w.) $1 \mathrm{~h}$ before irradiation (George et al., 1999).

The animals were divided into:

- Group1-( Control rats).

- Group 2-(.- Animals irradiated at the dose level of $7 \mathrm{~Gy}$

- Group3-.(Caffeine treated animals)

- Group4- (Animals injected with caffeine and then irradiated at a dose level of $7 \mathrm{~Gy}$ ).

The animals were scarified one and three days after treatment. Fresh liver specimens were obtained and paraffin sections (6um thickness) were prepared for histological study. More fresh liver specimens were also obtained where frozen sections (8um thickness) were prepared for histochemical study. Different histochemical techniques, were used for localization of the activity of enzyme including.

1- Gomori technique for Acid phosphatase enzyme activity (Pearse, 1975).

2- Modified Gomori technique for Alkaline phosphatase enzyme activity (Pearse , 1975).

3- Nachlas technique for succinic dehydrogenase enzyme activity (Nachlas, $\boldsymbol{e t}$ al., 1957 and Pearse, 1975).

Quantitative analysis were carried out to evaluate the enzymatic reaction using computer image analysing system. The system is supplied by research microscope and colored video camera. Estimation of the optical density (0.D) was done. The obtained results were statistically analyzed.

\section{Result \\ 1-Morphological changes (Fig 1,2).}

The normal histological pattern of the liver of rats was found as normal hepatic cords radiated from the central vein and separated by narrow blood sinusoids. The hepatocytes were polyhydral cells with acidophilic cytoplasm and each had a rounded nucleus. The group exposed to $\gamma$ rays ( 7 Gy) showed peri portal fibrosis with some necrotic hepatic tissue after 1 day which persisted for the three days in addition to pyknotic nuclei and vaculated cytoplasm. In the group of animals treated with caffeine alone, hepatic cells showed nearly normal histological pattern. On the other hand in case of animals exposed to $\gamma$ rays combined with caffeine, hepatic cells showed mild vaculation with dilated blood sinusoids after one day of exposure which persisted for the three days.

\section{2- Histochemical changes}

A- Acid phosphatase enzyme (ACP)(Fig 3-4).

After one day of the treatment there is a significant increase in the enzyme activity in all groups while after three days the enzyme activity increased after irradiation and decreased in both caffeine alone group and caffeine irradiated group.

\section{B- Alkaline phosphatase enzyme (ALKP)} (Fig 5-6):

After one day there is a significant increase in the enzyme activity in both caffeine alone group and caffeine irradiated group and a decrease in the irradiated group. After three days there is a significant increase in the enzyme activity in all the treated groups.

\section{C- Succinic dehydrogenase enzyme (SD)(Fig 7-8):}

The enzyme activity of succinic dehydrogenase significantly increased in all the treated groups after one and three days. 


\section{Omaima, S. Essa et al}

Table (1): Histochemical change in the hepatic cells under the effect of caffiene after one day in the different groups of the study

\begin{tabular}{|c|c|c|c|c|c|c|c|c|c|c|c|c|}
\hline \multirow[b]{2}{*}{ Cellular } & \multicolumn{4}{|c|}{ Acid phosphatase } & \multicolumn{4}{|c|}{ Alkaline phosphatase } & \multicolumn{4}{|c|}{ Succinic dehydrogenase } \\
\hline & control & $\begin{array}{c}\text { radiate } \\
\text { d }\end{array}$ & treated & $\begin{array}{c}\text { tre }+ \\
\text { rad }\end{array}$ & control & $\begin{array}{c}\text { radiate } \\
\text { d }\end{array}$ & treated & $\begin{array}{c}\text { tre + } \\
\text { rad }\end{array}$ & control & \begin{tabular}{|c|} 
radiate \\
d
\end{tabular} & treated & $\begin{array}{c}\text { tre }+ \\
\text { rad }\end{array}$ \\
\hline 1.00 & 1.44 & 1.48 & 1.39 & 1.42 & 1.27 & 1.28 & 1.44 & 1.65 & 1.50 & 1.86 & 1.57 & 1.71 \\
\hline 2.00 & 1.43 & 1.53 & 1.54 & 1.45 & 1.36 & 1.29 & 1.37 & 1.71 & 1.44 & 1.58 & 1.62 & 1.74 \\
\hline 3.00 & 1.36 & 1.65 & 1.42 & 1.36 & 1.34 & 1.25 & 1.56 & 1.72 & 1.57 & 1.65 & 1.65 & 1.69 \\
\hline 4.00 & 1.44 & 1.42 & 1.47 & 1.41 & 1.43 & 1.29 & 1.36 & 1.65 & 1.50 & 1.61 & 1.51 & 1.65 \\
\hline 5.00 & 1.37 & 1.57 & 1.37 & 1.42 & 1.44 & 1.32 & 1.46 & 1.69 & 1.47 & 1.54 & 1.66 & 1.73 \\
\hline 6.00 & 1.42 & 1.45 & 1.51 & 1.44 & 1.35 & 1.27 & 1.35 & 1.73 & 1.45 & 1.68 & 1.49 & 1.68 \\
\hline mean & 1.41 & 1.52 & 1.45 & 1.42 & 1.37 & 1.28 & 1.42 & 1.69 & 1.49 & 1.65 & 1.58 & 1.70 \\
\hline S.D & 0.04 & 0.08 & 0.07 & 0.03 & 0.06 & 0.02 & 0.08 & 0.03 & 0.05 & 0.11 & 0.07 & 0.03 \\
\hline S.E & 0.01 & 0.03 & 0.03 & 0.01 & \multirow[t]{4}{*}{0.03} & 0.01 & 0.03 & 0.01 & 0.02 & 0.05 & 0.03 & 0.01 \\
\hline Gr.comp & & $C: R$ & $\mathrm{C}: \mathrm{T}$ & C:TR & & $C: R$ & C:T & C:TR & & $\mathrm{C}: \mathrm{R}$ & C:T & C:TR \\
\hline T.value & & 0.04 & 0.08 & 0.30 & & 0.01 & 0.13 & 0.00 & & 0.01 & 0.01 & 0.00 \\
\hline Significance & & S. $\uparrow$ & N.S. $\uparrow$ & N.S. $\uparrow$ & & S. $\downarrow$ & S. $\uparrow$ & S. $\uparrow$ & & S. $\uparrow$ & S. $\uparrow$ & S. $\uparrow$ \\
\hline
\end{tabular}

Table (2): Histochemical changes in the hepatic blood vessels under the effect of caffiene after one day in the different groups of the study

\begin{tabular}{|c|c|c|c|c|c|c|c|c|c|c|c|c|}
\hline \multirow{2}{*}{ cellular } & \multicolumn{5}{|c|}{ acid phosphatase } & \multicolumn{4}{|c|}{ alkaline phosphatase } & \multicolumn{3}{|c|}{ Succinic dehydrogenase } \\
\hline & control & radiated & treated & tre + rad & control & radiated & treated & tre + rad & control & Radiated & treated & tre + rad \\
\hline 1.00 & 1.08 & 1.05 & 1.12 & 1.05 & 1.13 & 1.16 & 1.19 & 1.16 & 1.08 & 1.2 & 1.19 & 1.21 \\
\hline 2.00 & 0.85 & 1.13 & 1.11 & 1.02 & 1.14 & 1.21 & 1.14 & 1.19 & 1.03 & 1.22 & 1.2 & 1.28 \\
\hline 3.00 & 0.98 & 1.03 & 0.9 & 1.03 & 1.13 & 1.13 & 1.22 & 1.14 & 1.99 & 1.23 & 1.09 & 1.08 \\
\hline 4.00 & 0.9 & 1 & 0.98 & 0.91 & 1.18 & 1.11 & 1.24 & 1.17 & 1.07 & 1.22 & 1.24 & 1.24 \\
\hline 5.00 & 1.01 & 1.09 & 0.92 & 0.92 & 1.16 & 1.14 & 1.06 & 1.11 & 1.05 & 1.21 & 1.21 & 1.17 \\
\hline 6.00 & 1.06 & 1.05 & 0.89 & 0.98 & 1.12 & 1.09 & 1.17 & 1.15 & 1.04 & 1.81 & 1.17 & 1.18 \\
\hline mean & 0.98 & 1.06 & 0.99 & 0.99 & 1.14 & 1.14 & 1.17 & 1.15 & 1.21 & 1.32 & 1.18 & 1.19 \\
\hline S.D & 0.09 & 0.05 & 0.10 & 0.06 & 0.02 & 0.04 & 0.06 & 0.03 & 0.38 & 0.24 & 0.05 & 0.07 \\
\hline S.E & 0.04 & 0.02 & 0.04 & 0.02 & 0.01 & 0.02 & 0.03 & 0.01 & 0.16 & 0.10 & 0.02 & 0.03 \\
\hline Gr.comp & & $C: R$ & C:T & C:TR & & $\mathrm{C}: \mathrm{R}$ & $\mathrm{C}: \mathrm{T}$ & C:TR & & & C:T & C:TR \\
\hline T.value & & 0.07 & 0.46 & 0.45 & & 0.44 & 0.19 & 0.26 & & 0.31 & 0.44 & 0.46 \\
\hline significance & & S. $\uparrow$ & N.S. $\uparrow$ & N.S. $\uparrow$ & & S. & N.S. $\uparrow$ & N.S. $\uparrow$ & & S. $\uparrow$ & S. $\downarrow$ & S. $\downarrow$ \\
\hline
\end{tabular}


Table (3): Histochemical changes in the hepatic cells under the effect of caffiene after three day in the different groups of the study.

\begin{tabular}{|c|c|c|c|c|c|c|c|c|c|c|c|c|}
\hline \multirow{2}{*}{ cellular } & \multicolumn{4}{|c|}{ Acid phosphatase } & \multicolumn{4}{|c|}{ Alkaline phosphatase } & \multicolumn{4}{|c|}{ Succinic dehydrogenase } \\
\hline & control & radiated & treated & tre + rad & control & radiated & treated & tre + rad & control & radiated & treated & tre + rad \\
\hline 1 & 1.42 & 1.55 & 1.41 & 1.38 & 1.44 & 1.48 & 1.39 & 1.42 & 1.5 & 1.73 & 1.68 & 1.61 \\
\hline 2 & 1.56 & 1.52 & 1.37 & 1.39 & 1.36 & 1.53 & 1.54 & 1.45 & 1.48 & 1.55 & 1.59 & 1.73 \\
\hline 3 & 1.48 & 1.45 & 1.34 & 1.41 & 1.41 & 1.42 & 1.42 & 1.52 & 1.5 & 1.49 & 1.72 & 1.75 \\
\hline 4 & 1.43 & 1.54 & 1.42 & 1.37 & 1.44 & 1.65 & 1.39 & 1.41 & 1.45 & 1.61 & 1.56 & 1.68 \\
\hline 5 & 1.47 & 1.5 & 1.38 & 1.39 & 1.43 & 1.52 & 1.47 & 1.36 & 1.42 & 1.66 & 1.7 & 1.77 \\
\hline 6 & 1.5 & 1.52 & 1.41 & 1.42 & 1.36 & 1.57 & 1.4 & 1.45 & 1.52 & 1.53 & 1.56 & 1.70 \\
\hline Mean & 1.48 & 1.51 & 1.39 & 1.39 & 1.41 & 1.53 & 1.44 & 1.44 & 1.48 & 1.60 & 1.64 & 0.06 \\
\hline S.D & 0.05 & 0.04 & 0.03 & 0.02 & 0.04 & 0.08 & 0.06 & 0.05 & 0.04 & 0.09 & 0.07 & 0.02 \\
\hline S.E & 0.02 & 0.01 & 0.01 & 0.01 & 0.02 & 0.03 & 0.02 & 0.02 & 0.02 & 0.04 & 0.03 & C:TR \\
\hline Gr.comp. & & $\mathrm{C}: \mathrm{R}$ & $\mathrm{C}: \mathrm{T}$ & C:TR & & $\mathrm{C}: \mathrm{R}$ & $\mathrm{C}: \mathrm{T}$ & C:TR & & $\mathrm{C}: \mathrm{R}$ & C:T & 0.00 \\
\hline T.value & & 0.13 & 0.01 & 0.00 & & 0.01 & 0.22 & 0.20 & & 0.02 & 0.00 & 0.00 \\
\hline Significance & & N.S. $\uparrow$ & S. $\downarrow$ & S. $\downarrow$ & & S. $\uparrow$ & N.S. $\uparrow$ & N.S. $\uparrow$ & & S. $\uparrow$ & S. $\uparrow$ & S. $\uparrow$ \\
\hline
\end{tabular}

Table (4): Histochemical changes in the hepatic blood vessels under the effect of caffiene after three day in the different groups of the study.

\begin{tabular}{|c|c|c|c|c|c|c|c|c|c|c|c|c|}
\hline \multirow{2}{*}{ Cellular } & \multicolumn{4}{|c|}{ acid phosphatase } & \multicolumn{4}{|c|}{ alkaline phosphatase } & \multicolumn{4}{|c|}{ succinic dehydrogenase } \\
\hline & control & radiated & treated & tre + rad & Control & radiated & treated & tre + rad & control & radiated & treated & tre + rad \\
\hline 1 & 1.26 & 1.43 & 1.14 & 1.11 & 1.08 & 1.05 & 1.12 & 0.93 & 1.05 & 1.25 & 1.17 & 1.22 \\
\hline 2 & 1.22 & 1.37 & 1.24 & 1.15 & 1.14 & 1.03 & 1.11 & 0.9 & 1.09 & 1.2 & 1.21 & 1.19 \\
\hline 3 & 1.27 & 1.33 & 1.17 & 1.16 & 1.11 & 1.13 & 0.98 & 0.99 & 1.15 & 1.3 & 1.25 & 1.27 \\
\hline 4 & 1.26 & 1.36 & 1.03 & 1.13 & 0.85 & 1.09 & 0.92 & 0.98 & 1.2 & 1.27 & 1.27 & 1.18 \\
\hline 5 & 1.28 & 1.33 & 1.15 & 1.14 & 0.98 & 1 & 0.89 & 0.03 & 1.08 & 1.22 & 1.23 & 1.17 \\
\hline 6 & 1.23 & 1.27 & 1.13 & 1.08 & 1.06 & 1.06 & 0.96 & 0.05 & 1.01 & 1.31 & 1.25 & 1.21 \\
\hline mean & 1.25 & 1.35 & 1.14 & 1.13 & 1.04 & 1.06 & 1.00 & 0.65 & 1.10 & 1.26 & 1.23 & 1.21 \\
\hline S.D & 0.02 & 0.05 & 0.07 & 0.03 & 0.11 & 0.05 & 0.10 & 0.47 & 0.07 & 0.04 & 0.04 & 0.04 \\
\hline S.E & 0.01 & 0.02 & 0.03 & 0.01 & 0.04 & 0.02 & 0.04 & 0.19 & 0.03 & 0.02 & 0.01 & 0.01 \\
\hline Gr.comp & & $\mathrm{C}: \mathrm{R}$ & $\mathrm{C}: \mathrm{T}$ & C:TR & & $\mathrm{C}: \mathrm{R}$ & C:T & C:TR & & $\mathrm{C}: \mathrm{R}$ & $\mathrm{C}: \mathrm{T}$ & C:TR \\
\hline T.value & & 0.00 & 0.01 & 0.00 & & 0.32 & 0.14 & 0.05 & & 0.00 & 0.01 & 0.01 \\
\hline significance & & S. $\uparrow$ & S. $\downarrow$ & S. $\downarrow$ & & N.S. $\uparrow$ & S. $\downarrow$ & S. $\downarrow$ & & S. $\uparrow$ & S. $\uparrow$ & S. $\uparrow$ \\
\hline
\end{tabular}



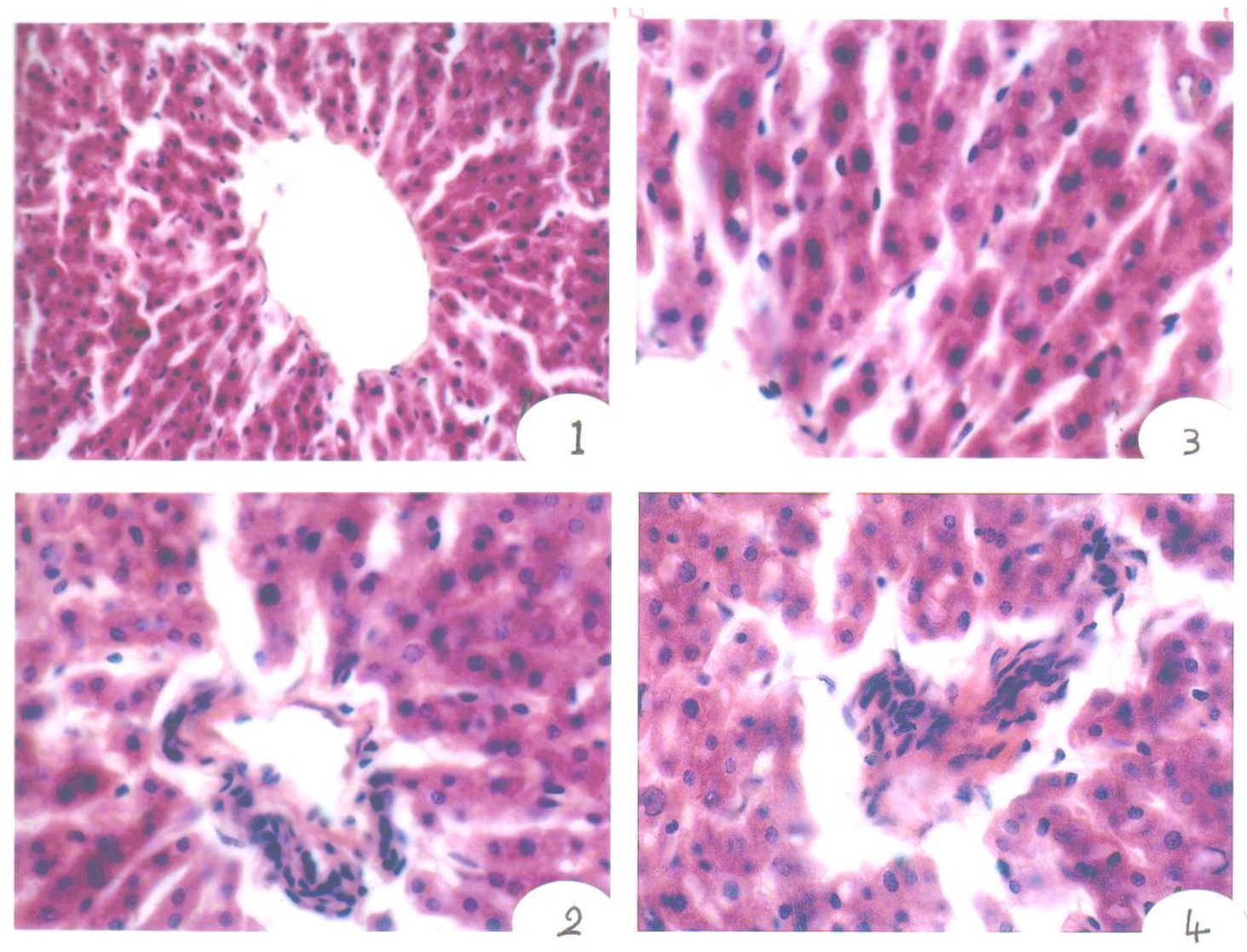

Fig (I): Photomicrograph of section in the rat liver after (one) day 1): Section of control liver showing normal liver

2): section of liver exposed to gamma rays showing periportal fibrosis and with somenecrotic hepatic tissue and cellular infiltration.

3): Section of Liver treated with caffeine showing picture more or less as a control. 4): Section liver exposed to gamma ray and treated with caffeine showing cellular infiltration with dilated blood sinusoids

(Hx \&E X 500). 

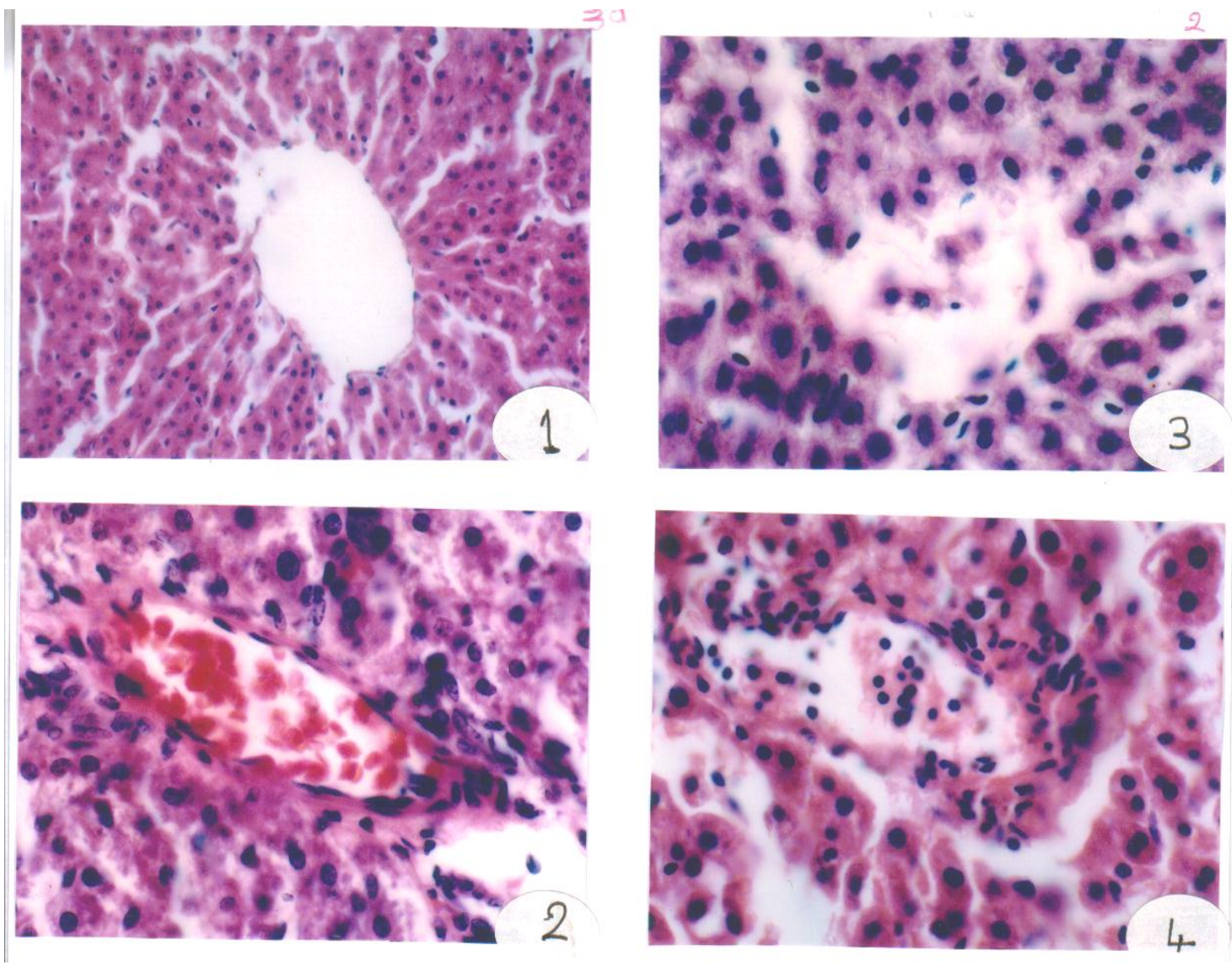

Fig (2): Photomicrograph of section in the rat liver after (three) day:

1): Section of control liver showing normal liver.

2): Section of liver exposed to gamma ray showing periportal fibrosis, necrosis of hepatic cell some showing pyknotic nuclei with vacuolated cytoplasm.

3): Section of liver treated with caffeine showing picture more or less as a control group with changes in hepatic nuclei.

4): Section of liver exposed to gamma ray and treated with caffeine showing dilated blood sinusoids and vacuolated hepatocytes and some cellular infiltration.

(Hx \&E x500). 

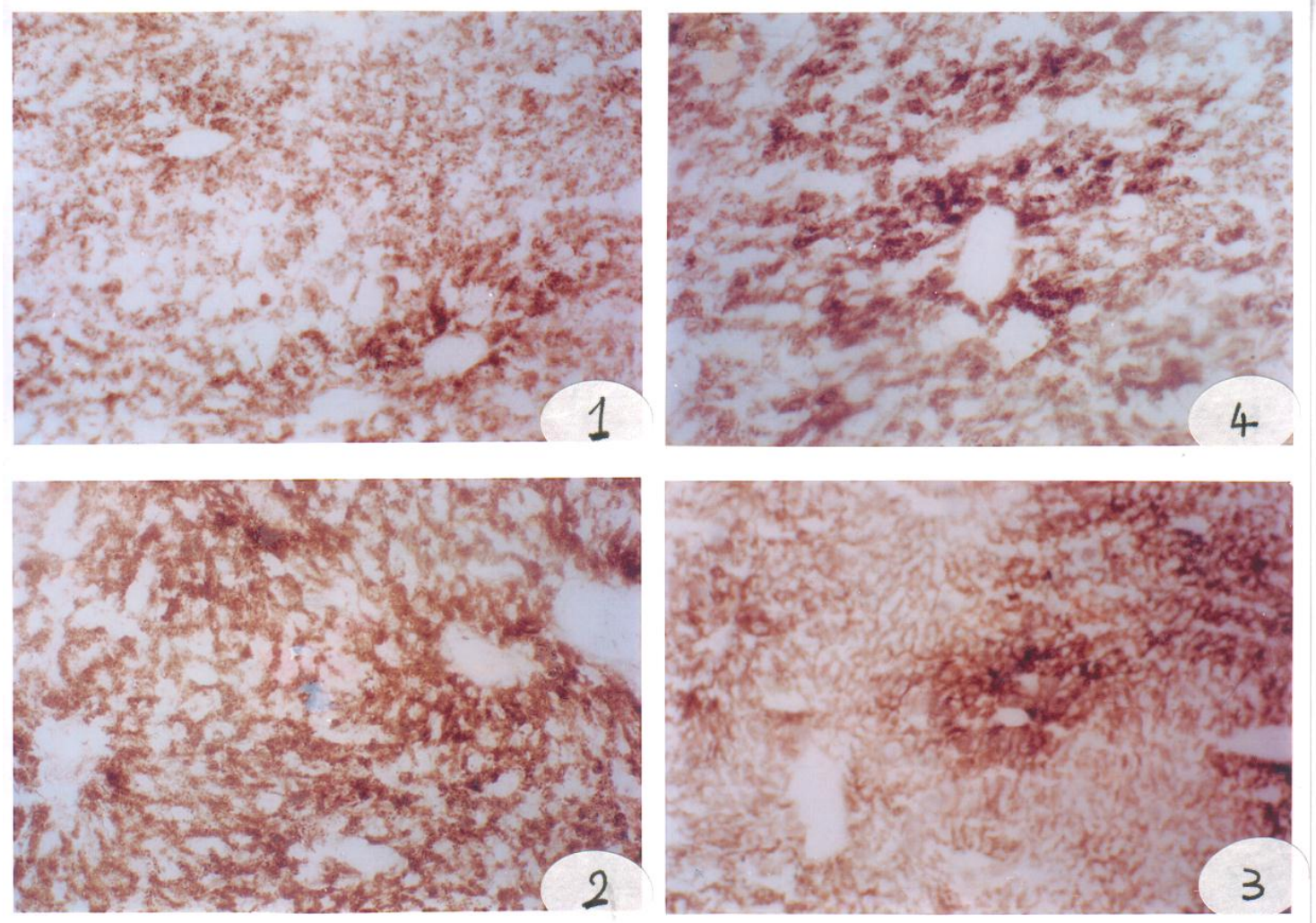

Fig (3): Photomicrograph section in the rat liver after (one) day showing acid phosphatase enzyme activity.

1): Section of control liver showing normal liver activity.

2): Section of liver exposed to gamma rays showing increase in the acid phosphatase enzyme activity.

3): Section of liver treated with caffiene showing increase in the acid phosphatase enzyme activity.

4): Section of liver exposed to gamma ray and treated with caffiene showing similar to control in the acid phosphatase enzyme activity.

(Gomori tech., X400). 

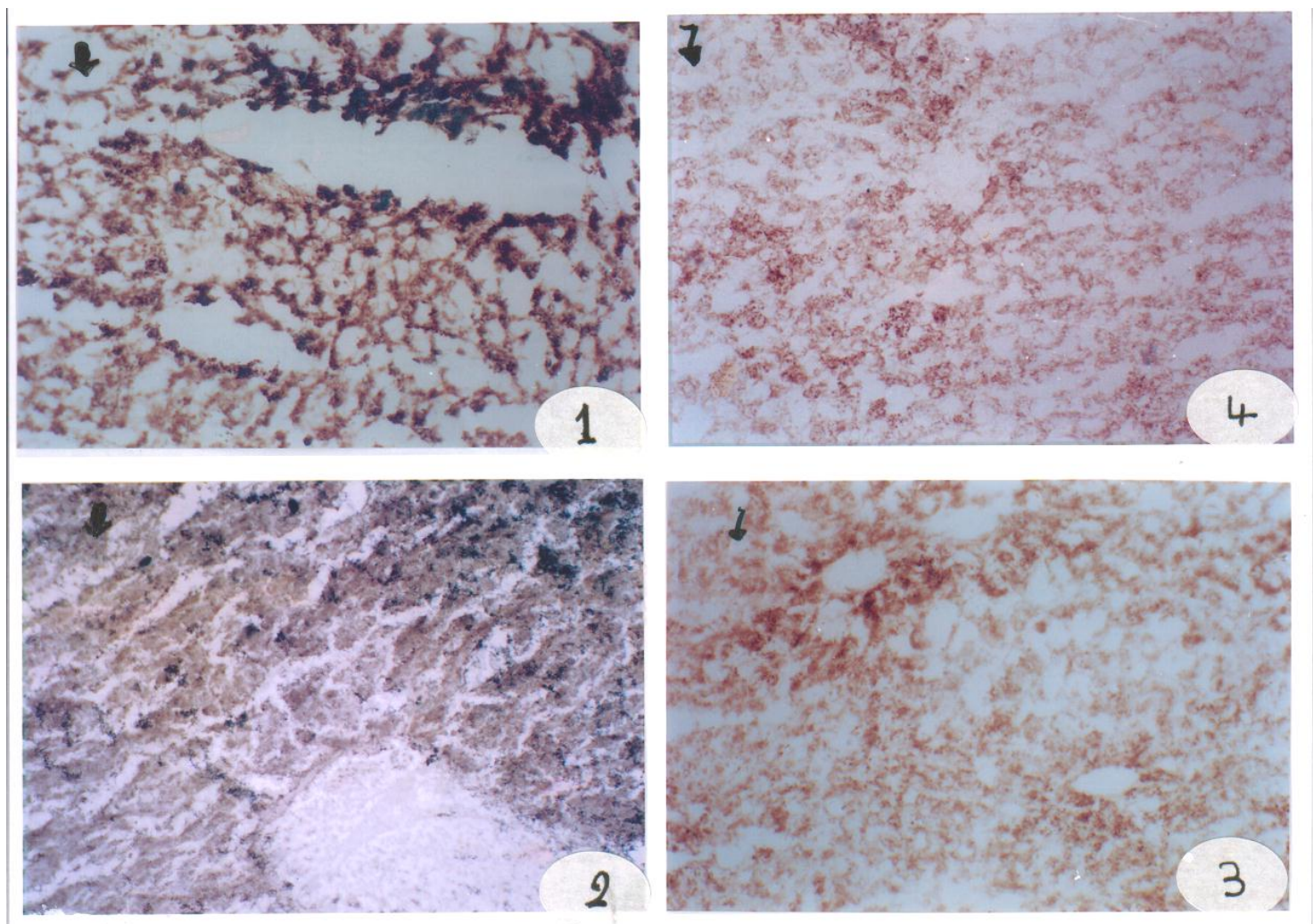

Fig (4): Photomicrograph section in the rat liver after (three ) days showing acid phosphatase enzyme activity..

1): Section of control liver showing normal liver activity.

2): Section of liver exposed to gamma rays showing increase in the acid phosphatase enzyme activity.

3): Section of liver treated with caffeine showing decrease in the acid phosphatase enzyme activity.

4): Section of liver exposed to gamma rays and treated with caffeine showing decrease in the acid phosphatase enzyme activity.

(Gomori tech., X 400) 



Fig (5): Photomicrograph of section in the rat liver after (one) day showing alkaline phosphatase enzyme activity.

1) Section of control liver showing normal liver activity.

2) Section of liver exposed to gamma rays showing decrease in the alkaline phosphatase enzyme activity.

3) Section of liver treated with caffeine showing moderat in the alkaline phosphatase enzyme activity.

4) Section of liver exposed to gamma rays and treated with caffeine showing increase in the alkaline phosphatase enzyme activity.

(Modified Gomori. Tech., X 400 ) 

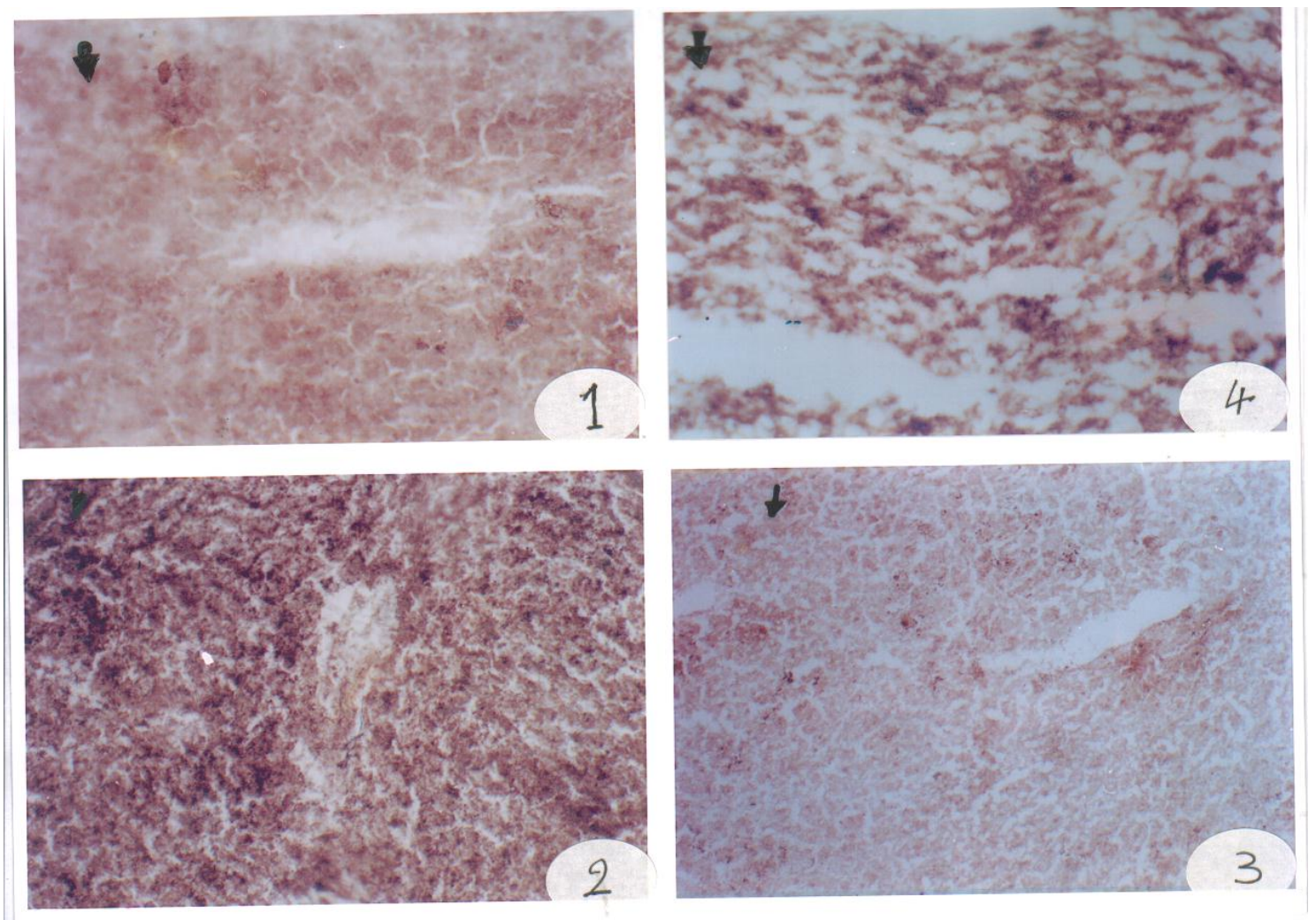

Fig (6): Photomicrograph of section in the rate liver after (three) days showing alkaline phosphatase enzyme activity.

1): Section of control liver showing normal liver activity.

2): Section of liver exposed to gamma rays showing increase in the alkaline phosphatase enzyme activity.

3): Section of alkaline treated with caffeine showing increase in the alkaline phosphatase enzyme activity.

4): Section of liver exposed to gamma ray and treated with caffeine showing increase in the alkaline phosphatase enzyme activity.

(Modified Gomori tech., X 400) 


\section{Omaima, S. Essa et al}
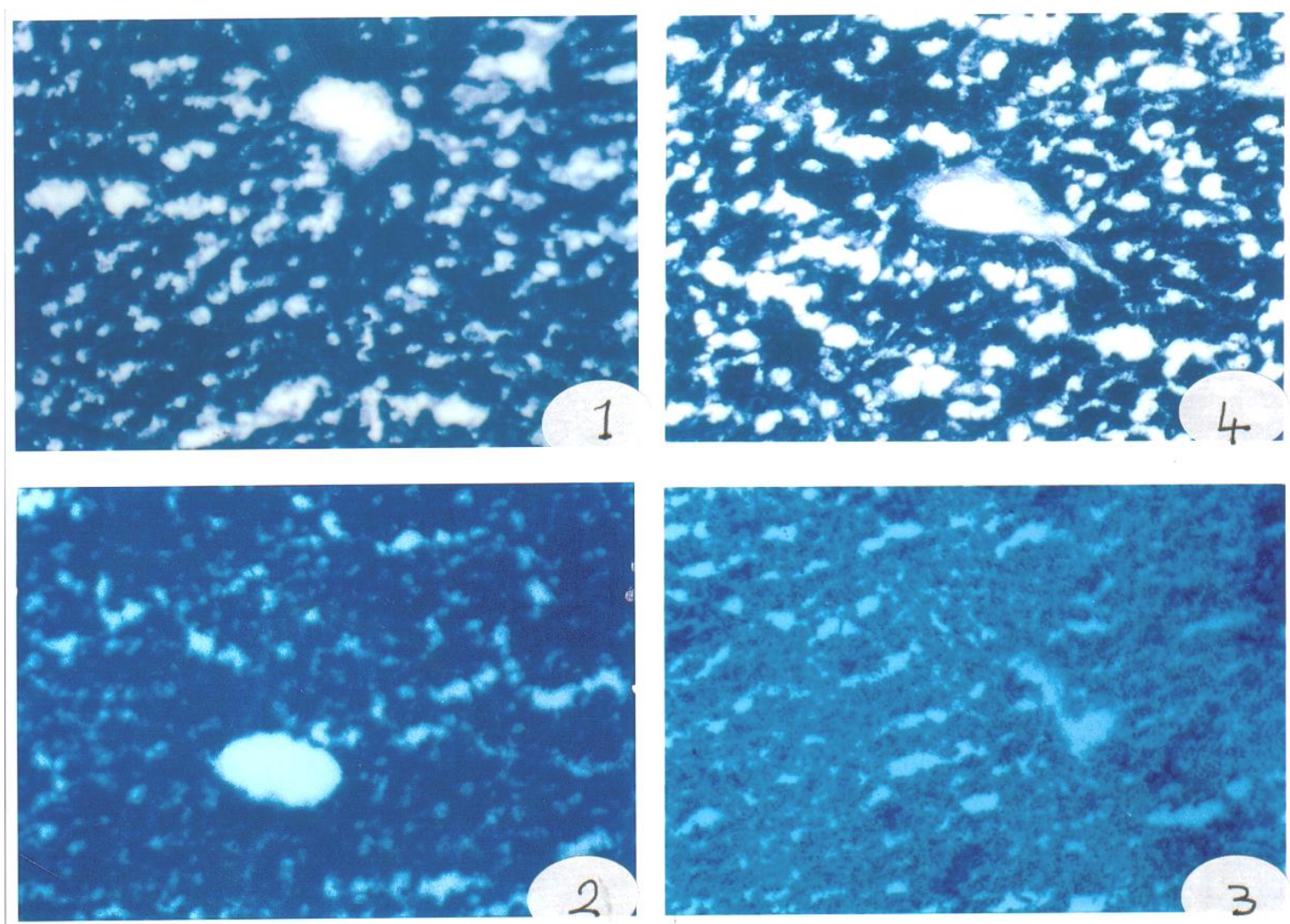

Fig (7): Photomicrograph of section in the rat liver after (one ) day showing succinic dehydrogenase enzyme activity.

1): Section of control liver showing normal activity.

2): Section of liver exposed to gamma rays showing increase in the succinic dehydrogenase enzyme activity.

3): Section of liver treated with caffeine showing decrease in the succinic dehydrogenase enzyme activity.

4): Section of liver exposed to gamma rays and treated with caffeine showing increase in the succinic dehydrogenase enzyme activity.

(Nachlas tech., X400). 

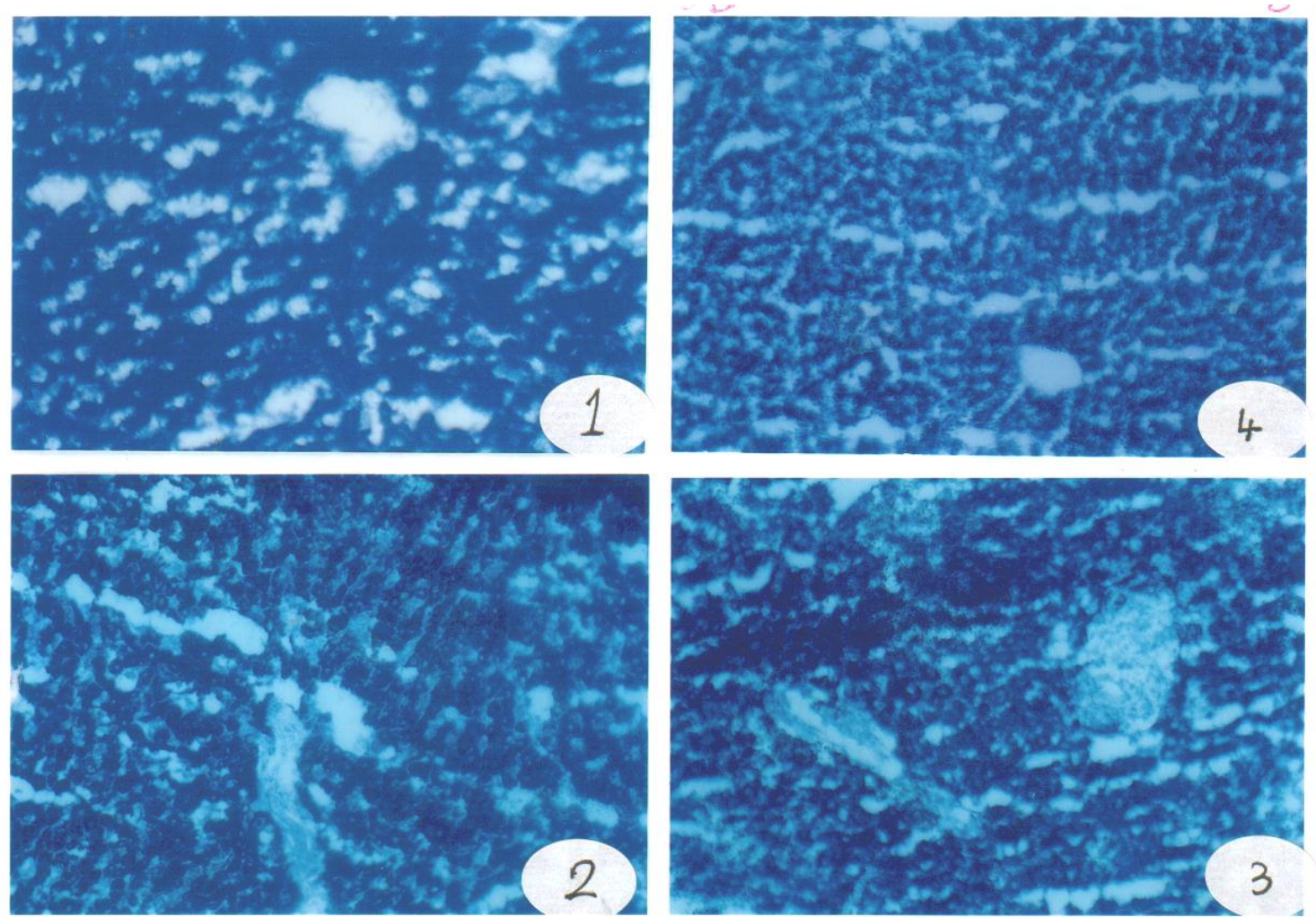

Fig (8): Photomicrograph of sections in the rat liver after (three) days showing succinic dehydrogenose activity.

1): Section of control liver showing normal liver activity.

2): Section of liver exposed to gamma rays showing increase in the succinic dehydrogenase enzyme activity.

3): Section of liver treated with caffeine showing increase in the succinic dehydrogenase enzyme activity.

4): Section liver exposed to gamma rays and treated with caffeine showing increase in the succinic dehydrogenasa enzyme activity.

(Nachlas tech. X 400). 
Omaima, S. Essa et al

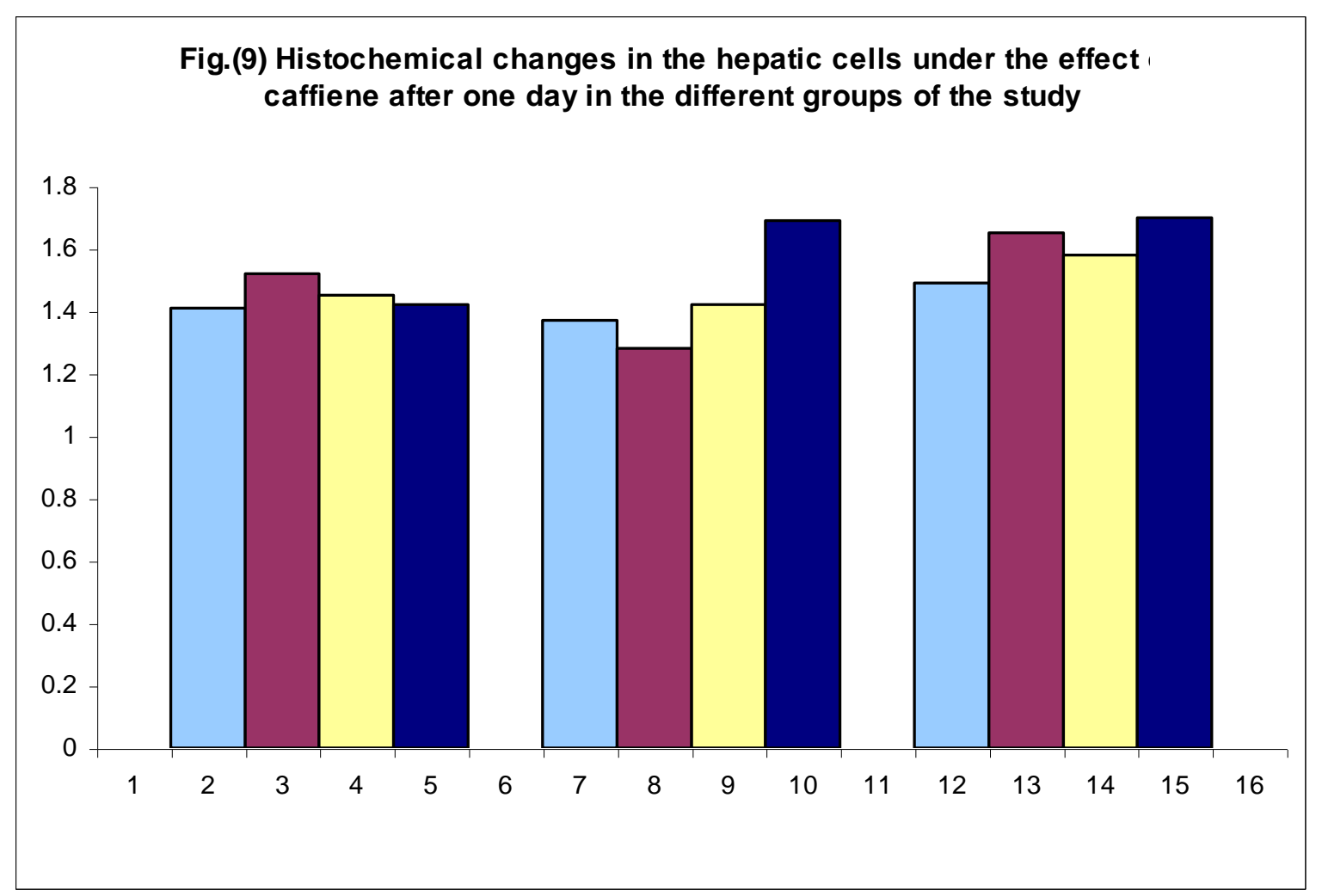

Fig.(10):Histological changes in the hepatic cells under the efect of Caffeine after three days in the different groups of the study




Histological and Histochemical Studies.......

Fig.(11): Histolological changes in the hepatic blood vessels under the effect of Caffiene after one day in the different groups of the study

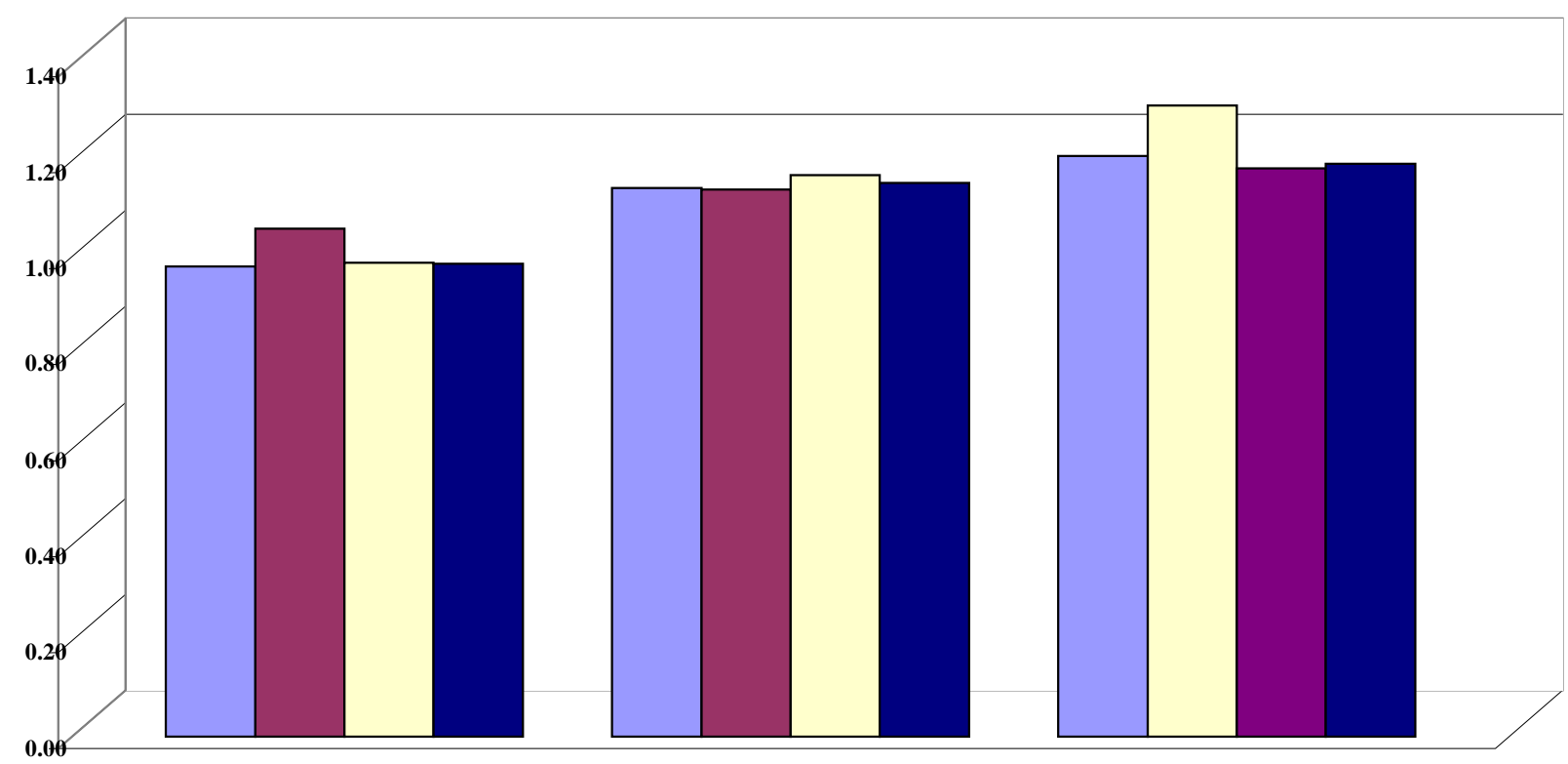

Fig.(12): Histochemical changes in the hepatic blood vessels under the effect of Caffeine after 3 days in the different groups of the study

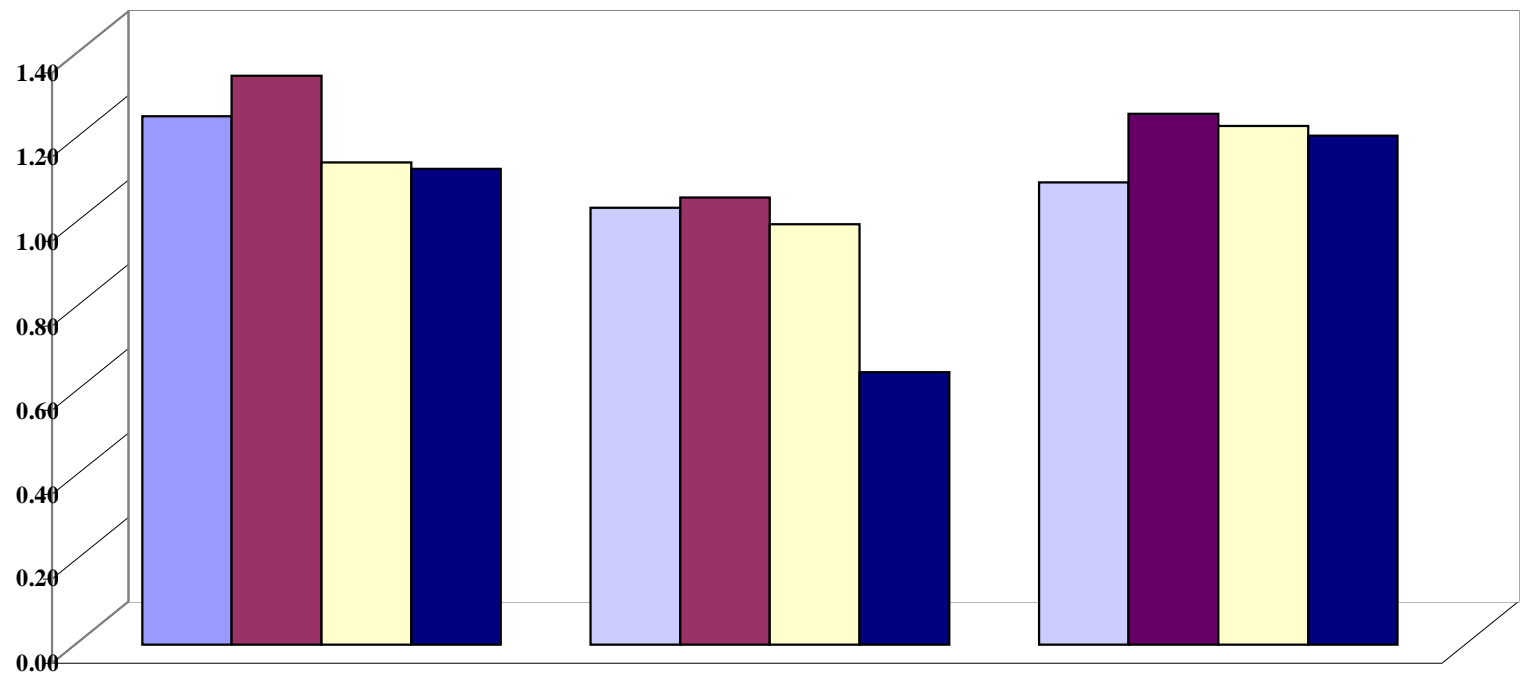




\section{Omaima, S. Essa et al}

\section{Discussion}

It has been found in the present study, that $\gamma$-irradiation at the exposure level (7 Gy), produced morphological alteration in the structure of the liver cells of rats.

According to Fawcett (1997), tissues are composed of parenchymal cells, which carry out the function of the tissue together with supportive elements e.g. connective tissue and blood vessels which transport metabolites to the parenchymal cells for the tissues which contain postmitotic parenchymal cells, such as the liver.

High doses are required to damage the parenchymal cells, but only moderate doses are needed to damage the vasculative tissue. Massive radiation doses are required to produce effects directly in the parenchymal cells of such tissue. It is well known that whole body irradiation of animals alters the metabolism of various organs. In the liver, which is one of the most radioresistant organs (Alekseev et al., 1984), whole body irradiation caused changes in the enzymatic activities, El-Kashef et al., 1989.

Our results showed significant changes in the activity of acid phosphatase, alkaline phosphatase and succinic dehydrogenase enzymes activity in the liver subjected to radiation hazard. The changes in the activity of acid phosphatase enzyme was highly related to radiation dose and post irradiation period (Lee, et al., 1994).

The present study showed significant increase in acid phosphatase enzyme activity in hepatic tissue either cells or blood vessels of irradiated rats and these results are in a greement with Goutier and Goutier (1962) who noticed liberation of acid phosphatase enzyme from lysosmal rat liver after irradiation with doses of 1- 7 Gy.

Rene et al. (1971), who assumed that there was a progressive changes in liver lysosmes of rats exposed to X-rays with the cellular necrobiotic process after irradiation. They added that the release of the enzymes may be related to an increase of cellular necrobiosis following irradiation. The biochemical results correlated well with the cytochemical studies and showed that in addition to the increase in the number and size of lysosomes, there was a distinct increase in acid phosphatase in the lysosmes themse-lves. The persistently high level of acid phosphatase in the cytoplasm was a possible indication of early radiation impairment of the lysosomal membrane.

Zyss and Kaszezynska (1972), observed an increase in the activity of acid phosphatase enzyme in lysosomes of liver cells in rats following a radiation dose of 10 Gy to the whole body at 24 hour \& 48 hours and 72 hours post-irradiation.

Shah and Gadhia (1977), noticed significant increase in the level of acid phosphatase in liver, kidney and spleen after sublethal doses of gamma irradiation (2 and 4 Gy) at different post-exposure intervals (24, 48 and 72 hours) in pigeon.

Snyder and Ekeland (1978), stated that cell destruction and increased lysosomal enzyme activities following various doses of whole body gamma- irradiation were observed in kidney, liver and intestine.

Choi et al. (1985), stated that the specific activity of acid phosphatase increased gradually after an exposure to 0.5 - 8.5 Gy of gamma-rays, reached maximum values from 1 to 7 hours post-irradiation.

Kotb et al. (1991), noticed that irradiated mice with a single dose of 7 or 14 Gy of fast neutron, showed an increase in the acid phosphatase activity during the $7^{\text {th }}$ post-irradiation in the liver. They added that the activity of the enzyme showed tendancy to return to the pre-irradiation levels with time.

The increase in acid phosphatase enzyme activity detected in this group can be attributed to the necrotic changes in the cells as this enzyme is concerned with the intracellular digestion. Alkaline phosphatase enzyme is a membrane bound glycoprotein is used as a marker enzyme for the plasma membrane and one of its most interesting aspects is easily inducible in response to various stimuli (Knolwes et al.,, 1979), Its activity had been found in the inter cellular as on the surface membrane (Seetharam et al., 1977), Our results showed significant decrease in the activity of alkaline phosphatase enzyme one day post exposure in the hepatic cells and blood vessels of rats exposed to (7 Gy) $\gamma$-rays 
while it increase after three days of exposure.

The decrease in the alkaline enzyme activity which observed in the present study is similar to different pathological condition. In case of mercury intoxication (Sastry and Roo, 1981), during starvation (Moussa et al., 1987) and in antibiotic treatment (EL-Behi et al., 1993 and 1998).

The present data showed that administration of caffeine to rats prior to radiation exposure appears capable of reducing the response recorded in enzyme activity of both acid phosphatase and alkaline phosphatase and succinic dehydrogenase in liver tissue.

The modifying role of the caffeine could be attributed to its action in scavenging free radicals produced after radiation exposure (George et al., 1999).

Respect to the suggestion of several investigator who have long experience with radioprotector in general and caffeine in particular (Kesavan et al., 1978 and Devasagayam et al., 1996) replace the death as the end point with experiments involving simpler tests systems or mammalian cell for assessing the ability of compound to modyfy the biological effects of ionizing radiation.

Caffeine considerad as an inhibitory compound scavenging the reactive forms of carcenogens, when present during exposure to high energy photons competes with oxygen for electrons and scavenges hydroxyl radical and single oxygen, (Kesavan, 1992). Caffeine can provide remarkable radioprotection to lethally irradiated mice $(7.5 \mathrm{~Gy})$ in view of the report that consumption of coffee resulted in a significant reduction of severe late radiation toxicity in normal tissue injury after irradiation of patients undergoing radiotherapy for servical cancer (Stelezer et al., 1994).

Caffeine has a dual function as a radioprotector of well oxygenated normal cells and a sensitizer of hypoxic tumor cells (George et al, 1999), the fact that helped in improvement in cancer radiotherapy (Tsuchiya et al. 2000). George et al. (1999) concluded that studies with death as the end point have confirmed the radioprotective action of caffeine, and pointed to the fact that caffeine concentration and the time of administration are critical for optimal radioprotection. It might be pointed that much lower doses are required to provide protection in radiotherapy and among occupational workers.

\section{References}

1. Alekseev, G. L.; Korovkin, B. F.; Mikhaleva, N. P. and Fedotov, G. M. (1984): Effect of lethal and supralethal doses of gamma-irradiation on the lysosomal enzyme activity in radiosensitive and radio-resistant tissues in the rat. Vopr, Med. Khim., 95.

2. Bhartiya, H. G. and Khan, S. A. (1983): Modification of acid phosphatase activity in the liver of Swiss albino mice by 2 -mercaptopropionylgl-ycin against gamma irradiation. Radiobiol. Radiother., 24: 23523

3. Broner, C. W.; Shenep, J. L.; Stidham, G. L.; Stakes, D. C. and Hildner, W. K. (1988): Effect of scavenger of oxygenderived free radicals on mortality in mice. Care Med., 16 (9)" 816-848.

4. Choi, K. N.; Wither, H. R. and Rothman, M. N. (1985): Interacranial metastases from melanoma clinical featurs and treatment by accelerated faction tion Cancer, 56:

5. Devasagayam, T. P. A, Kamat J. P, Hari $M$ and Kesavan P C(1996): Caffeine as an antioxidant: inhibition of lipid peroxidation induced by reactive oxygen species. Biochim. Biophys. Acta., 1282: 63-70.

6. EL-Beih;Z. M.; AMer, M. A.and Elew, F. H. (1993): Histoenzymology alterations in the succinic dehydrogenase activity in the cells of mice administered erythromy-cin. Proc. Egypt. Acad. Sci., 43: 113-121.

7. Beih, Z. M.; Amer, M. A. and Ateia, M.A. (1998): Effect of narcotics on the mitoch-ondria and succinic dehydrogenase activity of the intestinal epithelial cells of mammals. Egypt. J.Histol., 2 (2) : 281-292.

8. El-Kashef, H. S.; Roushdy, H. M.; Saada, H. N. and abd Elsamie, M. (1989): Protection from radiation induced changes in liver and serum transaminases of whole body irradiated rats. Egypt. Rad. Sci, Appl., 6, 129.

9. Fawcett, D. W. (1997): Bloom and Fawcett: Conics Histology. Roland P. Jensh, Contributing Editor. Champan and 
Hall, International Thomson Publishing USA.

10. George, K. C., Hebbar, S. A.; Kale, S. P and Kesavan, P. C. (1999): Caffeine protects mice against whole body lethal dose of gamma irradiation. J. Radiol. Prot, 19 (2): 171.

11. Goutier, P. H. and Goutier, R. P. (1962): Acid deoxyribonuclease and acid phosphatase activities in regenerating rat liver after whole body X-irradiation. Radiat. Res., 16: 728-735.

12. Kesavan, P. C. (1992): Protection by caffeine against oxic radiation damage and chemical carcinogens. Mechanistic considerations. Curr. Sci. 62: 791.

13. Kesavan, P. C.; Sharma, G. J. and Afzal, M.L.(1978):Differential modification of oxic and anoxic radiation damage by chemicals. Rad. Res. 75, 18.

14. Knowles, D.M.; Hoffman, H.T.; Ferraini M. and Kunkel, H.G. (1979): Acid naphthyl acetate esterase activity in human neoplastic lymphoid cells. Am.J.Phothol., 96:257-278.

15. Kotb, M. A.; Abd El-Mawla, A.; ElKhatib, A. and Ramadan, M. I. (1991): Effect of whole body irradiation by fast neutrons on mouse tissues. Pt. 1. Activity of acid phosphatase and succinic dehydrogenase in kidney, lung and liver. Iso top. Red. Res., 27 (3): 97-100.

16. Lee, K. S.; Cheon, K. L.; Kin, K. C.; Kim, J. K.; Kim, I. K. and Park, H. K.(1994): Development of technology for biological dosimetry. A study on the radiation and environmenta safety. Jul., 85.

17. Nachlas, M.; Tsou, K.; DeSouza, E.; Change, C. and Seligman, A. (1957): Cytochemical demonstration of succinic dehydrogenase by use of new p-nitrophyl substituted ditetrazol. J. Histochem. Cytochem., 6: 420-436.

18. Moussa, T.A.; El-Beih, Z.M. and Amer, M.A. (1987): Changes in the acid phosphatase and succinic dehydrogenase activities in mammalian gastric glandular cells induced by insecticide intoxication and stravation. Egypt. J. Histol., 10(1): 129138.
19. Packer, L. (1991): Protective role of vitamins in biological system. Am. J. Clin. Nutr., 53: 1050S-55S.

20. Pearse, A. G. (1975): Histochemistry Theoretical and Applied, Vol. $3^{\text {rd }}$ ed. P 150 Williams and Wilkins Co., Baltimare, Londonand New York.

21. Rene, A. A.; John, H. D. and Joseph, L. P. (1971): Radiation induced ultrastructural and biochemical changes in lysosomes. Lab. Invest., 25 (3): 230-239.

22. Sastry, K. V. and Rao, D. R. (1981): Enzymological and biochemical changes produced by mercuric in a teleost fish, Channa punctatus. Toxicol. Lett., 9 (4):421326.

23. Seetharam, B.; Yeh, K.; Moog, F. and Alpers, D.H. (1977): Development of intestinal brush border membrane protein in rat. Biochem. Biophys. Acta., 470-424.

24. Snyder, S. L. and Ekeland, S. K. (1978): Radiation induced alterations of lysosomal hydrolases in rat spleen homogenates. Radiat. Res., 75: 91-97.

25. Shah, V. C. and Gadhin, P. K. (1977): Effects of sublethal doses of gamma irradiation on phosphatases and succinate dehydrogenase levels in liver, kidney and spleen of pigeon. Indian J. Exp. Bio., 15: 1216-1217.

26. Stelzer, K. J.; Koh, W. J.; Kurtz, H.; Greer, B. E. and Griffin, T. W. (1994): Caffeine consumption is associated with decreased severe late toxicity after irradiation of pelvis. Int. J. Rad. Oncol. Biol. Phys., 30, 411.

27. Tsuchiya H, Yamamoto N, Asada N, Terasaki T, Kanazawa Y, Takanaka I, Nishijima H, Tomita K. (2000): Caffeinepotentiated radiochemothe-rapy and function-saving surgery for high-grade soft tissue sarcoma. Anticancer Res. 2000 MayJun; 20 (3B): 2137-43

28. Zyss, R. andKaszezynska, M. (1972). lysosomal system of liver cells in rats following a radiation dose of 100 rat. Acta. Med. Td., 13 (2): 177-192. 


\section{دراسات هستولوجية وهستوكيميائية على دور الكافيين فى تأثير الإشعاع على الكبد}

*أميمة سليمان عيسى ، **عبد الموجود أنس إسماعيل ، **:اشرف محمود مصطفى

* المركز القومى لبحوث وتكنولوجيا الإشعاع ، هيئة الطاقة الذرية الأزية

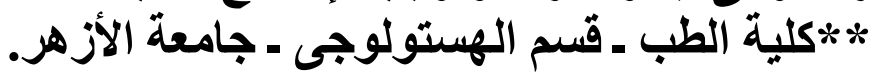

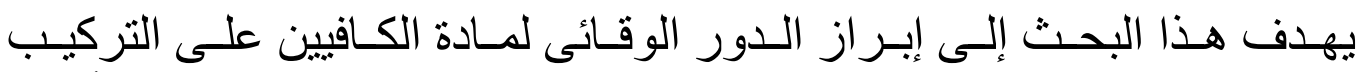

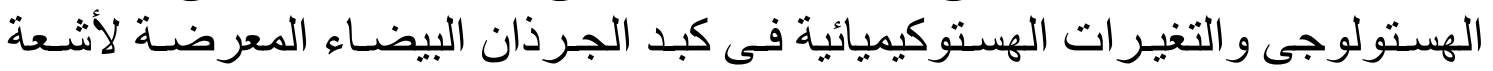

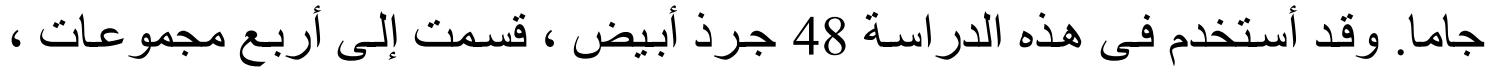

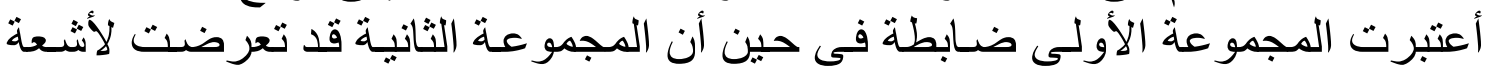

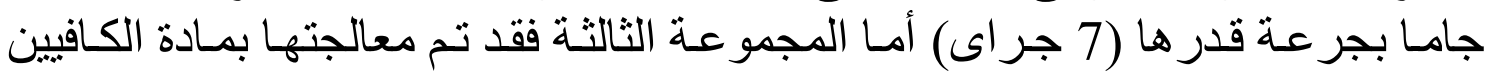

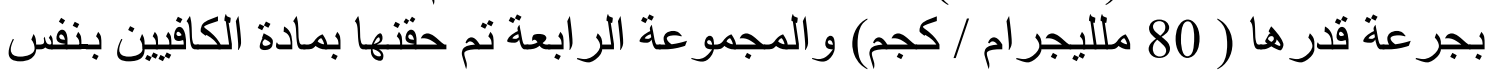

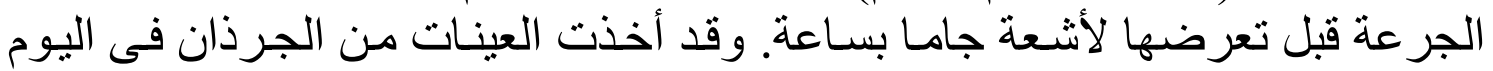
الأول و الثالث من تعرضها للإنشعاع.

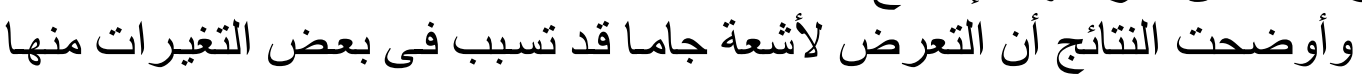

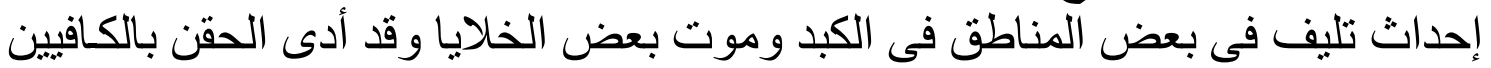

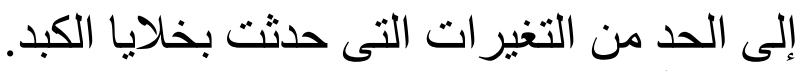

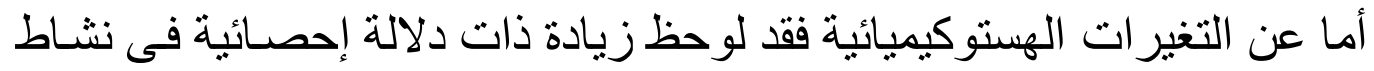

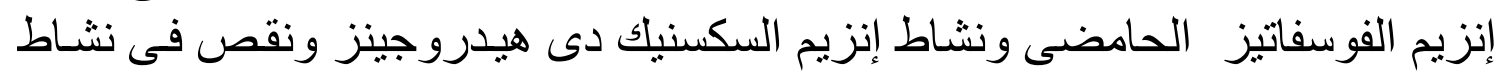

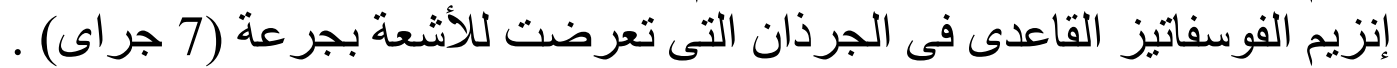

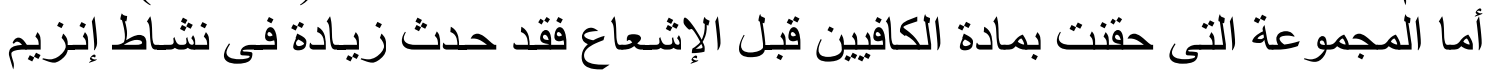
الفوسفاتيز القاعدى و إنزيم الفوسفاتيز الحامضى وإنزيم السكسينيك دهيدرو الانين فينز. 